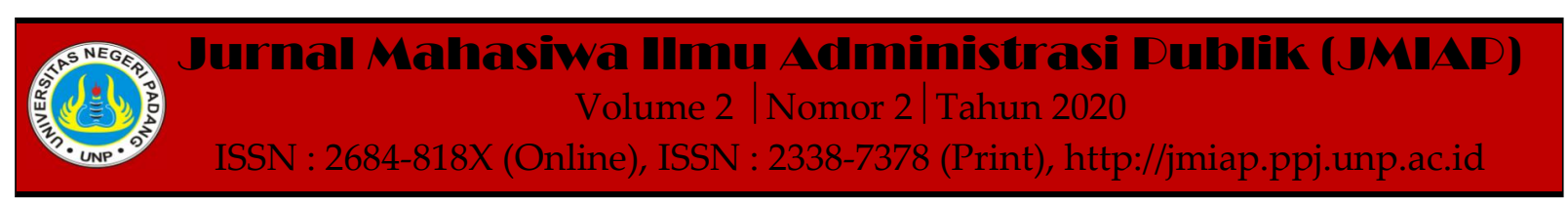

\title{
FAKTOR-FAKTOR YANG MEMPENGARUHI PERANAN KEPEMIMPINAN KETUA KUB DALAM MEMBERDAYAKAN NELAYAN DI KECAMATAN IV JURAI KABUPATEN PESISIR SELATAN
}

\author{
Sifa Urrahma ${ }^{1(a)}$, Fitri Eriyanti $^{2(b)}$ \\ ${ }^{1}$ Jurusan Ilmu Administrasi Negara, Universitas Negeri Padang \\ ${ }^{2}$ Jurusan Ilmu Administrasi Negara, Universitas Negeri Padang \\ a)sifaurrahmaa@gmail.com, ${ }^{b}$ fitri.eriyanti@fis.unp.ac.id
}

\begin{abstract}
This article aims to analyze the factors that affect the role of leadership KUB's leader $(K U B)$ in fisherman empowerment in IV Jurai sub-district Pesisir Selatan district. This research categorize 3 of KUB according to Pesisir Selatan fishery service category. The data were collected by observation, interview, and documentation. The informants of this research are fishery instructor, leader and members of KUB. The results indicate that there are several factors affect the Role of leadership KUB's leader in fisherman empowerment in IV Jurai sub-district Pesisir Selatan district. Among them are (1) Transparancy and Accountanbility of KUB's leader, (2) the ability of leader to motivate, (3) the concern of leader to members welfare, (4) leader's social position in society, (5) leader's experience and skill, (6) commitment of leader and members of $K U B$, (7) and resources in group

Keywords : Fishermn Empowerment, KUB, Role of Leadership

Corresponding author. Email.sifaurrahmaa@gmail.com, fitri.eriyanti@fis.unp.ac.id

How to cite this article. Urrahma, S \& Eriyanti, F. (2020). Faktor-Faktor yang Mempengaruhi Peranan Kepemimpinan Ketua KUB dalam Memberdayakan Nelayan di Kecamatan IV Jurai Kabupaten Pesisir Selatan. Jurnal Mahasiwa Ilmu Administrasi Publik (JMIAP) Jurusan Ilmu Administrasi Negara Fakultas Ilmu Sosial Universitas Negeri Padang, Volume 2 (2), Hal. 34-43.

http://jmiap.ppj.unp.ac.id

ISSN : 2684-818X (Online), ISSN : 2338-7378 (Print)

Copyright $(2020$. Published by Pusat Kajian-Pemberdayaan dan Pelayanan Masyarakat (PK-P2M) FIS UNP Padang
\end{abstract}




\section{PENDAHULUAN}

Pemerintah melakukan upaya pemberdayaan nelayan dengan tujuan untuk meningkatkan kesejahteraan nelayan. Salah satu upaya pemberdayaan nelayan dilakukan dengan membentuk kelembagaan berupa kelompok-kelompok nelayan. Hal ini di atur dalam UU No 7 Th 2016 pasal 54 tentang perlindungan dan pemberdayaan nelayan yang menyatakan bahwa "pemerintah pusat dan pemerintah daerah sesuai dengan kewenangannya melakukan pembinaan untuk pengembangan kelembagaan yang terbentuk. Selanjutnya PP No 50 Th 2015 tentang pemberdayaan nelayan kecil dan pembudidaya ikan kecil pada pasal 1 ayat 5 menegaskan "Kelompok Usaha Bersama (selanjunya disingkat KUB) merupakan badan usaha yang dibentuk oleh nelayan kecil berdasarkan hasil kesepakatan atau musyawarah seluruh anggota yang dilandasi oleh keinginan bersama untuk berusaha bersama dan dipertanggungjawabkan secara bersama guna meningkatkan pendapatan anggota". KUB didirikan atas dasar kesamaan kepentingan, potensi sumber daya ikan, kondisi lingkungan, lokasi administratif, atau sarana penangkapan ikan. KUB berfungsi untuk melayani kepentingan anggota dalam teknis, usaha, dan sosial kemasyarakatan

Ketua atau pemimpin dalam kelompok nelayan berperan penting dalam mengembangkan kelompoknya. Hal ini didukung pernyataan Amanah, (2014:3) salah satu dari sembilan faktor yang merupakan ciri-ciri kelompok yang berdaya adalah dengan adanya kepemimpinan yang situasional. Hal ini membuktikan bahwa pemimpin memegang peran penting dalam pengembangan kelompok, karena pemimpin akan menggerakan anggota kelompok untuk mengembangkan usahanya. Kepemimpinan yang tepat dalam menjalankan akifitas kelompok dapat menunjang tercapainya efektivitas kelompok.

Menurut Hasibuan, (2009:42) kreativitas dan dinamika seorang pemimpin dalam menjalankan kepemimpinannya akan sangat menentukan apakah tujuan tercapai atau tidak. Jika pemimpin dinamis dan kreatif maka organisasi yang dipimpinnya juga akan semakin dinamis dan aktifitasaktifitas yang akan dilakukan semakin banyak. Sebaliknya jika pemimpin tidak kreatif maka organisasi yang dipimpinnya pun akan melempem. Kegiatan dan dinamika yang terjadi dalam sebuah organisasi sebagian besar di tentukan oleh cara pemimpin memimpin organisasinya. Pemimpin harus mengutamakan tugas dan tanggung jawab dan membina hubungan yang harmonis dalam organisasi. Dari penelitian Hafizhoh (2011:63) ditemukan bahwa kepemimpinan berhubungan nyata dengan tercapainya efektivitas kelompok. Hal ini menunjukan bahwa adanya pengaruh kepemimpinan terhadap efektivitas kelompok

Di Kabupaten Pesisir Selatan jumlah masyarakat yang berprofesi sebagai nelayan sangat banyak. Menurut data dari Dinas Perikanan Kabupaten Pesisir Selatan jumlah nelayan pada tahun 2019 mencapai 18.848 orang. Pada umumnya nelayan itu sudah berkelompok dalam bentuk KUB.

Adapun jumlah KUB di Kabupaten Pesisir Selatan dapat dilihat pada tabel di bawah ini.

\section{Tabel 1. Jumlah KUB di Kabupaten Pesisir Selatan}

\begin{tabular}{clc}
\hline No & Nama Kecamatan & $\begin{array}{c}\text { Jumlah } \\
\text { KUB }\end{array}$ \\
\hline 1 & Koto XI Tarusan & 13 \\
2 & Bayang & 6 \\
3 & IV Jurai & 14 \\
4 & Batang Kapas & 3 \\
5 & Sutera & 12 \\
6 & Lengayang & 4 \\
7 & Ranah pesisir & 3 \\
8 & Linggo Sari Baganti & 6 \\
9 & Air Pura & 2 \\
\hline & Jumlah & $\mathbf{6 1}$
\end{tabular}

Sumber: Dinas Perikanan Kabupaten Pesisir Selatan (2019) 
Meskipun banyak terdapat KUB di Kabupaten Pesisir Selatan namun tidak semua KUB berhasil memberdayakan anggotanya dengan baik. Hasil survey awal yang peneliti lakukan, terlihat hampir $85 \%$ nelayan di Kabupaten Pesisir Selatan tergolong nelayan yang belum memiliki kemandirian, keterampilan, dan kemampuan dalam melaut termasuk mengolah hasil tangkapannya. Ketidakberdayaan nelayan itu berimbas pada tingkat penghasilan mereka yang tergolong rendah.

\section{TINJAUAN PUSTAKA}

\section{Pengertian Peran}

Soerjono Soekanto (2002:243), menyatakan peran ialah aspek dari kedudukan dan status seseorang, seseorang dikatakan menjalankan peran jika ia mampu untuk menjalankan hak dan memenuhi kewajiban sesuai dengan kedudukannya. Peran juga merupakan suatu konsep tentang apa yang dilakukan oleh seseorang dalam kehidupan bermasyarakat. Peran mencakup norma yang dikembangkan sesuai kedudukan seseorang. Sedangkan menurut Suhardono (1994:3) peran merupakan fungsi yang dibawa seseorang saat ia mengemban suatu jabatan dalam struktur sosial.

Dari penjelasan diatas dapat dipahami bahwa peran berkaitan dengan posisi atau kedudukan seseorang. Jika dikaitkan dengan pemimpin dalam kelompok nelayan maka peran pemimpin kelompok akan terlihat ketika ia mampu untuk memenuhi segala hak dan kewajibannya sebagai pemimpin dalam kelompok.

Kemudian pengertian peran juga dikemukakan oleh Abu Ahmadi (1982:50) peran diartikan sebagai suatu kompleks pengharapan manusia terhadap caranya individu harus bersikap dan berbuat dalam situasi tertentu yang berdasarkan status dan fungsi sosialnya didalam masyarakat.

Dari pendapat Ahmadi dapat disimpulkan bahwa peran merupakan harapan tentang cara seseorang yang memiliki jabatan tertentu dalam bersikap dan menjalankan fungsi dari kedudukannya tersebut.

\section{Pengertian Kepemimpinan}

Richard L.Hughes dalam Wirawan (2014:8) mengemukakan konsep kepemimpinan sebagai ilmu dan seni. Sebagai ilmu kepemimpinan punya objek, metode, teori dan penelitian ilmiah. Kemudian kepemimpinan juga merupakan suatu seni yaitu kepemimpinan diterapkan dalam praktik memimpin sistem sosial. Orang yang menguasai ilmu kepemimpinan belum tentu bisa menjadi pemimpin yang baik dan sebaliknya banyak pemimpin yang sukses tanpa pernah mempelajari ilmu kepemimpinan secara khusus.

Sedangkan menurut Kouzes \& Posner (2004:20) kepemimpinan diartikan sebagai kemampuan seseorang mempraktikan keahlian yang dimiliki. Dalam hal ini Kouzes melihat kepemimpinan sebagai suatu kemampuan yang dimiliki oleh seseorang dan bagaimana ia mempraktikan kemampuan yang dimilikinya itu dalam bertindak sehingga terlihat bahwa ia memiliki jiwa kepemimpinan.

Jadi dapat kita simpulkan bahwa kepemimpinan merupakan pengetahuan yang dikuasai oleh seseorang dan dapat dilihat dari bagaimana ia mempraktikan pengetahuan dan kemampuannya tersebut dengan cara bekerjasama dengan orang lain.

\section{Pengertian Pemberdayaan Masyarakat}

Subejo dan Supriyanto (2004) mengemukakan pemberdayaan masyarakat sebagai upaya memberi fasilitas untuk masyarakat agar bisa mandiri dalam merencanakan dan memutuskan, dan mengelola sumberdaya yang mereka miliki dengan kegiatan tertentu yang membuat mereka mampu untuk mandiri secara ekonomi, sosial dan ekologi.

Sedangkan menurut Mardikanto (2015:28) pemberdayaan merupakan proses agar masyarakat mempunyai kekuatan untuk ikut aktif berpartisipasi dalam mengontrol serta memberi pengaruh pada kejadian-kejadian dan lembaga yang 
mempengaruhi kehidupannya. Istilah pemberdayaan juga dapat diartikan sebagai upaya memenuhi kebutuhan yang diinginkan oleh individu, kelompok dan masyarakat luas agar mereka memiliki kemampuan untuk melakukan pilihan dan mengontrol lingkungannya supaya bisa memenuhi keinginannya, termasuk aksesibilitasnya terhadap sumber daya yang terkait dengan pekerjaanya, aktivitas sosialnya dan lain sebagainya.

Dari pemaparan diatas dapat kita pahami arti dari pemberdayaan masyarakat adalah upaya dan proses untuk membangun masyarakat yang mandiri, kuat dan mampu memenuhi kebutuhannya serta mampu berpartisipasi dalam kehidupan sosial, karena itulah pemberdayaan tidak bisa dilakukan dalam proses jangka pendek melainkan harus melalui proses jangka panjang.

\section{Peranan Kepemimpinan Pemberdayaan Nelayan}

dalam

Ketua atau pemimpin dalam kelompok nelayan berperan penting dalam mengembangkan kelompoknnya. Hal ini sejalan dengan pendapat Amanah, (2014:3) yang menyatakan bahwa ciri-ciri kelompok yang berdaya adalah :

1. Memiliki visi dan misi yang jelas

2. Adanya kerjasama dalam mencapai tujuan

3. Kepemimpinan yang situasional

4. Adanya program dan kegiatan usaha produktif

5. Adanya komunikasi yang efektif dan pembelajaran

6. Adanya sarana dan prasarana kelompok

7. Adanya tekanan untuk bekerja lebih baik lagi

8. Adanya proses kaderisasi pembinaan anggota

Dari pernyataan diatas dapat diketahui bahwa salah satu dari sembilan faktor yang merupakan ciri-ciri kelompok yang berdaya adalah kepemimpinan. Karena itu peran dari kepemimpinan menjadi penting dalam melakukan pemberdayaan pada kelompok- kelompok nelayan. Menurut Munir (2009:211) pemimpin adalah penentu bagi berhasil atau tidaknya suatu organisasi. Karena ia dikatakan berhasil jika ia mampu untuk mengelola organisasi dan mempengaruhi anggota serta menunjukan jalan dan tindakan yang akan dilakukan secara bersama-sama.

Kapita,dkk (2016:2) mengemukakan bahwa dalam memberdayakan masyarakat dibidang sosial maupun ekonomi dibutuhkan seorang pemimpin, pemimpin yang dimaksud disini adalah pemimpin yang mampu menjadi sumber inovasi, memiliki kemampuan dalam membina serta mengarahkan, dan juga berfungsi sebagai komunikator untuk menyampaikan aspirasi agar kreatifitas dan inisiatif dari masyarakat untuk mengelola dan memelihara serta memanfaatkan sumber daya alam yang ada disekitarnya dapat meningkat sehingga kehidupan yang lebih baik.

Pembentukan KUB merupakan salah satu bentuk pemberdayaan masyarakat dalam kelompok nelayan dengan tujuan untuk meningkatkan kesejahteraan nelayan. Faktor kepemimpinan mempunyai pengaruh yang cukup besar bagi tercapainya efektivitas dan pengembangan KUB. Menurut Sjafri (2014:65) pada kepemimpinan kelompok kegiatan pemimpin ditekankan pada mengelola dan menggerakan anggota dalam kumpulan yang terorganisasi untuk mencapai tujuan bersama, hal ini meliputi tingkat kemampuan pemimpin dalam menggerakkan anggotanya, tingkat kemampuan pemimpin dalam memberikan informasi kepada semua anggota, dan juga tingkat kemampuan pemimpin dalam mengambil keputusan.

Dari pemaparan diatas dapat diambil kesimpulan bahwa pemberdayaan masyarakat merupakan upaya dan proses untuk membangun masyarakat yang mandiri, kuat dan mampu memenuhi kebutuhannya serta mampu berpartisipasi dalam kehidupan sosial, karena itulah pemberdayaan tidak bisa dilakukan dalam 
proses jangka pendek melainkan harus melalui proses jangka panjang.

\section{METODE PENELITIAN}

Penelitian ini menggunakan metode penelitian kualitatif, penelitian ini dilakukan di Kecamatan IV Jurai Kabupaten Pesisir Selatan. Alasan memilih Kecamatan IV Jurai sebagai lokasi penelitian karena di Kecamatan IV Jurai ini terdapat perbedaan yang signifikan antara satu KUB dengan KUB yang lainnya. Disini terdapat KUB yang sangat berhasil namun disisi lain juga terdapat KUB yang kurang aktif dan tidak aktif sama sekali meskipun KUB ini dibimbing oleh penyuluh yang sama dan diberikan materi yang sama oleh Penyuluh dari Dinas Perikanan Kabupaten Pesisir Selatan. Penelitian ini meneliti tiga KUB berdasarkan pengkategorian KUB menurut Dinas Perikanan Kabupaten Pesisir Selatan yaitu KUB Bangkit Bersama sebagai KUB yang maju, KUB Cahaya Langit sebagai KUB yang kurang maju, dan KUB Palapa Sago sebagai KUB yang tidak maju atau tidak berkembang. Informan dalam penelitian ditetapkan berdasarkan teknik purposive sampling. Informan terdiri dari ketua, segenap pengurus dan anggota ketiga KUB yang diteliti, dan penyuluh perikanan dari Dinas Perikanan Kabupaten Pesisir Selatan.

Data dikumpulkan melalui observasi, wawancara dan studi dokumentasi. Uji keabsahan data dilakukan dengan teknik triangulasi sumber. Teknik pengolahan data dengan reduksi, penyajian data dan penarikan kesimpulan.

\section{HASIL DAN PEMBAHASAN}

Dari data penelitian terdapat beberapa faktor yang mempengaruhi peran dari pemimpin dalam pemberdayaan nelayan di Kecamatan IV Jurai Kabupaten Pesisir Selatan, dapat diuraikan sebagai berikut :

\section{Keterbukaan dan Akuntabilitas Ketua Kelompok}

Akuntabilitas dalam kelompok sangat penting untuk menumbuhkan kepercayaan dari anggota. Hal ini sejalan dengan pendapat (Wirjana \& Supardo, 2006) akuntabilitas adalah suatu prinsip yang wajib dimiliki oleh pemimpin dan harus dituntut darinya. Akuntabilitas pada dasarnya merupakan pemenuhan dari janjijanji yang telah dibuat serta komitmen yang diberikan dan pertanggungjawaban dari apa yang telah dilakukan yang berkaitan dengan penggunaan wewenang yang telah diberikan. Pemimpin yang akuntabel fokus pada akhir tujuan organisasi dan hasil dari program yang telah dilaksanakan.

Dari hasil penelitian penulis pada KUB yang maju dan berkembang akuntabilitas dari ketua kelompok sangat baik, sedangkan pada KUB yang tidak berhasil ditemukan bahwa ketua kelompok kurang akuntabel. Padahal keterbukaan dan akuntabilitas dalam kelompok sangat penting untuk menumbuhkan kepercayaan dari anggota.

\section{Kemampuan Pemimpin dalam Mendorong Semangat}

Berdasarkan data penelitian kemampuan pemimpin untuk mengembangkan kelompok serta kemampuannya dalam memotivasi anggota merupakan salah satu faktor yang menentukan perannya di dalam kelompok, pada KUB yang maju kemampuan pemimpin dalam mendorong semangat anggota untuk aktif dalam kegiatan sangat baik, sedangkan pada KUB yang tidak maju pemimpin tidak ada inisiatif untuk mendorong semangat anggotanya agar aktif dalam kegiatan.

Menurut Sjafri (2014:65) salah satu faktor yang menyebabkan rendahnya kepemimpinan kelompok adalah karena kurangnya tanggung jawab dari pemimpin kelompok baik secara moral maupun secara material untuk menjaga, menyelamatkan dan mengembangkan kelompoknya dengan modal yang dimiliki menjadi lebih besar.

Kemudian Kouzes \& Posner, (2004:13) juga menyatakan bahwa pemimpin teladan yang berhasil melakukan hal luar biasa dalam organisasi menggunakan praktik yang sama diantaranya adalah menginsprirasi dan menyemangati jiwa. 


\section{Kepedulian Pemimpin terhadap \\ Kesejahteraan Anggota}

Tingkat kepedulian ketua menjadi salah satu faktor yang mempengaruhi keberhasilannya dalam pemberdayaan kelompok, hal ini sejalan dengan pendapat (Wirjana \& Supardo, 2006) Pemimpin harus memiliki kepedulian yang merupakan suatu sikap mencintai yang positif, karena jika mereka peduli maka mereka akan berbuat sesuatu untuk para anggotanya. Dari hasil penelitian pada KUB yang maju ketua KUB memiliki kepedulian yang tinggi terhadap masyarakatnya dan berusaha untuk mengembangkan potensi yang ada didaerahnya untuk tujuan meningkatkan kesejahteraan masyarakat.

\section{Kedudukan Sosial Pemimpin dalam Masyarakat}

Ketua KUB hendaknya adalah orang yang dihormati dan disegani oleh anggota, hal ini sejalan dengan pendapat Wirawan (2014:10) untuk menjadi seorang pemimpin seseorang harus memiliki syarat dan kualifikasi tertentu diantaranya pemimpin hendaknya merupakan elit anggota sistem sosial yang memiliki kualitas pendidikan, ekonomi dan status sosial yang lebih tinggi dari anggota sistem sosial lainnya.

Berdasarkan hasil penelitian penulis kedudukan sosial pemimpin berpengaruh terhadap kemauan anggota mengikuti apa yang disarankan atau yang disampaikan oleh ketua kelompok. Kedudukan sosial merupakan salah satu yang faktor yang mempengaruhi kepemimpinan ketua KUB.

\section{Pengalaman dan Kemampuan yang Dimiliki oleh Pemimpin}

Dari hasil penelitian pada KUB yang maju terlihat pengalaman dan kemampuan ketua KUB sangat baik yang menyebabkan ia mampu mengembangkan kelompoknya. Pemimpin yang berpengalaman dan memiliki kemampuan akan mendorong keberdayaan anggota kelompoknya, hal ini sejalan dengan yang disampaikan oleh Yuki dalam Marginingsih (2016:35) pemimpin berprilaku dengan memberikan contoh kepada anggota kelompoknya agar anggota mengikutinya, saat ia berhasil membuat anggota mengikutinya maka pemimpin akan bisa memberi pengaruh yang lebih disebabkan anggota telah memiliki kesamaan nilai serta keyakinan dengan pemimpin, hal ini akan meningkatkan motivasi dan kepuasan anggota.

\section{Komitmen}

Berdasarkan data dari hasil penelitian terlihat bahwa salah satu faktor yang menyebabkan KUB tidak berjalan sesuai dengan harapan adalah komitmen dalam pembentukan KUB, dapat dilihat dari adanya fenomena dimana KUB hanya dijadikan sebagai formalitas untuk menerima bantuan, kegiatan KUB tidak dijalankan dan anggota kelompok bukanlah nelayan, administrasi dalam KUB hanya disusun ketika ada bantuan saja.

Berdasarkan hasil penelitian Negara (2017:29) Komitmen nelayan anggota KUB berpengaruh positif secara signifikan terhadap pemberdayaan nelayan, dan pemberdayaan Nelayan anggota KUB berpengaruh positif terhadap peningkatan usaha nelayan, kemudian komitmen nelayan anggota KUB juga berpengaruh positif terhadap pengembangan usaha.

Dari penjelasan diatas dapat kita ketahui bahwa komitmen ketua dalam memimpin kelompok juga berpengaruh dalam keberlanjutan kelompoknya, menurut (Wirjana \& Supardo, 2006) kepemimpinan berkaitan dengan kemauan serta kemampuan untuk berubah, pemimpin haruslah memiliki visi, keberanian serta kemauan untuk tetap mau belajar dan tumbuh. Komitmen tidak hanya pada ketua kelompok namun juga pada anggota kelompok

\section{Sumber Daya yang Dimiliki oleh Kelompok \\ Sumber daya yang dimiliki dalam kelompok berpengaruh terhadap pengembangan kelompok tersebut, sumber daya baik berupa modal dan sumber daya manusia menunjang efektifitas kelompok}


nelayan, hal ini sejalan dengan pendapat Saepudin (2013:23) peran serta kemampuan dalam mengelola sumber daya (resources) berupa sumber daya alam ataupun sumber daya manusia sangat penting dalam pembangunan ekonomi, jumlah serta mutu dari sumber daya yang dimiliki juga menjadi faktor yang sangat penting. Sumber daya ini dapat dibagi menjadi tiga jenis berupa sumber daya alam, sumber daya modal serta teknologi yang dimiliki. Jika sumber daya alam dan sumber daya modal yang dimiliki tinggi maka akan menunjang bagi tercapainya pertumbuhan ekonomi, didalam kelompok nelayan hal ini akan mendukung pertumbuhan dan efektivitas kelompok, namun hal ini juga perlu didukung dengan kemampuan dalam menggali serta mengembangkan sumber daya tersebut, dalam hal ini seorang pemimpin yang mampu mengembangkan dan menggali sumber daya yang dimiliki akan membuat kelompoknya menjadi lebih maju dan berkembang, tentu saja hal ini dapat meningkatkan kesejahteraan nelayan.

Hal ini juga didukung oleh hasil penelitian Anwar (2017:92) ditemukan bahwa selain modal manusia faktor lain yang memiliki peranan dalam pertumbuhan ekonomi adalah investasi fisik berupa modal dan infrastruktur. Secara empiris kontribusi investasi memberikan nilai positif sehingga ketika mampu untuk dikembangkan akan meningkatkan perekonomian secara keseluruhan.

Dari pemaparan diatas dapat disimpulkan bahwa sumber daya yang dimiliki akan berpengaruh dalam pembangunan ekonomi, termasuk dalam kelompok nelayan , jika sumber daya yang dimiliki sudah bagus maka peluang kelompok untuk berkembang dan maju juga akan semakin besar. Karena itu perlu adanya sumber daya manusia yang memadai untuk menggali dan mengelola sumber daya yang ada tersebut.

\section{Upaya Meningkatkan Peranan Kepemimpinan Ketua KUB dalam Memberdayakan Nelayan di Kecamatan IV Jurai Kabupaten Pesisir Selatan}

Upaya untuk mengoptimalkan peran kepemimpinan ketua KUB dalam pemberdayaan nelayan sesuai dengan faktor-faktor yang mempengaruhi peran kepemimpinan ketua KUB dalam pemberdayaan nelayan di Kecamatan IV Jurai Kabupaten Pesisir Selatan dapat di uraikan sebagai berikut :

\section{a. Sasaran pemberdayaan harus tepat}

Salah satu faktor yang menyebabkan kegagalan pemberdayaan nelayan melalui KUB di kecamatan IV Jurai Kabupaten Pesisir Selatan adalah KUB hanya dijadikan sebagai formalitas untuk menerima bantuan, dimana pada beberapa KUB sebagian anggota kelompok bukanlah nelayan bahkan yang menjadi pengurus bukan nelayan melainkan pemilik kapal, karena itu penting untuk memastikan bahwa dalam pemberdayaan melalui KUB sasaran pemberdayaannya harus tepat.

Menurut Lizard (2017 Vol.2 No.2) tepat sasaran merupakan ketepatan pemberian bantuan program pemberdayaan kepada mereka yang dianggap sangat layak untuk menerima. Nelayan yang di berdayakan dalam kelompok adalah nelayan kecil, sesuai dengan PP No 50 Th 2015 KUB tentang pemberdayaan nelayan kecil dan pembudidaya ikan kecil pada pasal 1 ayat 5 menegaskan "Kelompok usaha bersama (selanjunya disingkat KUB) merupakan badan usaha yang dibentuk oleh nelayan kecil berdasarkan hasil kesepakatan atau musyawarah seluruh anggota yang dilandasi oleh keinginan bersama untuk berusaha bersama dan dipertanggung jawabkan secara bersama guna meningkatkan pendapatan anggota".

b. Pemimpin dalam kelompok harus memiliki jiwa sosial yang tinggi

Ketua KUB yang memiliki jiwa sosial tinggi akan selalu mengutamakan kepentingan bersama diatas kepentingan 
pribadi. Pemimpin seperti inilah yang dikatakan sebagai pemimpin yang ideal. Hal ini sejalan dengan pendapat (Wirjana \& Supardo, 2006) Kepemimpinan yang ideal adalah kepemimpinan yang menepatkan hidup sebagai pelayan dan bukan hanya pada karir semata pemimpin harus setingkat lebih terampil dari anggotanya.

c. Ketua kelompok hendaknya orang yang memiliki kedudukan sosial atau setidaknya dihormati dan dipercaya oleh anggotanya.

Ketua KUB hendaknya adalah orang yang dihormati dan disegani oleh anggota, hal ini sejalan dengan pendapat Wirawan (2014:10) untuk menjadi seorang pemimpin seseorang harus memiliki syarat dan kulifikasi tertentu diantaranya pemimpin hendaknya merupakan elit anggota sistem sosial yang memiliki kualitas pendidikan, ekonomi dan status sosial yang lebih tinggi dari anggota sistem sosial lainnya.

Menurut Sjafri (2014:120) peran pemimpin dalam kelompok terbagi menjadi dua pengaruh yaitu; (1) pengaruh secara impersonal. Yaitu karna adanya status pemimpin yang melekat pada diri seseorang. Status ini diperoleh karena ia dipilih oleh anggota kelompoknya. Ia diberikan kewenangan untuk memimpin kelompok tersebut. Kondisi objektif menggambarkan bahwa pemimpin kelompok memiliki kewenangan yang cukup besar dalam kelompok jika dibandingkan dengan anggotanya. Dengan adanya kewenangan yang lebih besar inilah pemimpin dapat menggunakan kewenangannya untuk mempengaruhi bawahannya untuk menyesuaikan dengan tujuan dari pemimpin tersebut; (2). Pengaruh secara personal yaitu pengaruh yang dilakukan oleh seorang pemimpin yang diakibatkan karena kemampuan persuasif yang secara khusus dimiliki oleh pemimpin tersebut. Dalam memerankan pengaruh secara personal akan membedakan antara pemimpin yang satu dengan pemimpin yang lain. d. Memberikan pelatihan-pelatihan kepemimpinan pada ketua KUB

Pada umumnya tingkat pendidikan nelayan masih sangat rendah sehingga menyebabkan pemimpin dalam kelompok nelayan ini tidak memiliki sumber daya manusia yang memadai dan juga kreatifitas dan keterampilan dalam mengembangkan kelompoknya. Karena itu penting untuk memberikan pelatihan-pelatihan kepemimpinan kepada ketua kelompok.

Menurut Jumiati (2018:2) salah satu faktor yang menyebabkan kemiskinan nelayan adalah karena rendahnya sumber daya yang dimiliki oleh nelayan baik itu sumber daya modal maupun sumber daya manusia. Karena itu penting untuk meningkatkan pengetahuan nelayan terutama anggota kelompok dengan melakukan pemberdayaan melalui pelatihan-pelatihan tertentu.

\section{PENUTUP}

Terdapat beberapa faktor yang mempengaruhi peran kepemimpinan ketua KUB dalam memberdayakan nelayan di Kecamatan IV Jurai Kabupaten Pesisr Selatan diantaranya adalah keterbukaan dan akuntabilitas ketua kelompok, kemampuan pemimpin dalam mendorong semangat, kepedulian pemimpin terhadap kesejahteraan anggota, Kedudukan sosial pemimpin dalam masyarakat, pengalaman dan kemampuan yang dimiliki oleh pemimpin, komitmen ketua maupun anggota dalam KUB, serta sumber daya yang dimiliki dalam kelompok.

Upaya untuk meningkatkan peran kepemimpinan ketua KUB dalam memberdayakan nelayan di Kecamatan IV Jurai Kabupaten Pesisir Selatan bisa dilakukan dengan memastikan bahwa sasaran pemberdayaan harus tepat, lalu pemimpin dalam kelompok harus memiliki jiwa sosial yang tinggi, kemudian ketua kelompok hendaknya orang yang memiliki kedudukan sosial atau setidaknya dihormati dan dipercaya oleh anggotanya, serta memberikan pelatihan-pelatihan kepemimpinan pada ketua KUB. 
Berdasarkan hasil penelitian tersebut faktor kepemimpinan ketua KUB terbukti memiliki pengaruh dalam keberdayaan kelompok maka hendaknya pemerintah rutin memberikan pelatihan-pelatihan kepemimpinan pada ketua kelompok agar kemampuan dan keterampilannya dapat berkembang. Kemudian Pemberdayaan harus dilakukan dalam jangka waktu yang panjang karena dalam melakukan pemberdayaan masyarakat perlu adanya upaya yang berkelanjutan, serta dibutuhkan adanya pembinaan baik dari pemerintah maupun pihak terkait, dalam hal ini keterlibatan perguruan tinggi juga dibutuhkan karena dengan adanya keterlibatan perguruan tinggi maka diharapkan akan meningkatkan pembinaan dan pengawasan dalam pemberdayaan nelayan

\section{DAFTAR KEPUSTAKAAN}

Ahmadi, Abu. (1982). Sosiologi Pendidikan: Membahas Gejala Pendidikan Dalam

Konteks Struktur Sosial

Masyarakat, Jakarta: Bina Ilmu

Amanah, S. (2014). Pemberdayaan Sosial Petani-Nelayan

Keunikan Agriekosistem Dan Daya Saing. Jakarta: Yayasan Pustaka Obor Indonesia.

Anwar, A. (2017). Peran Modal Manusia Terhadap Pertumbuhan Ekonomi Regional Di Jawa. Jurnal Economia, 92.

Hasibuan, M. S. (2009). Manajemen (Dasar,Pengertian,Dan Masalah). Jakarta: Pt

Bumi Aksara

Hafizhoh, A. (2011). Hubungan Gaya Kepemimpinan Terhadap Efektivitas

Kelompok (Kasus : Kelompok Tani Mekarsari, Desa Purwasari, Kecamatan Dramaga, Kabupaten Bogor). Bogor: IPB
Jumiati, I. E. (2018). Analisis Evaluasi Program Pemberdayaan Nelayan Tangkap Di Pelabuhan Perikanan Nusantara (Ppn) Karangantu Kota Serang. Journalof Indonesian Public Administration and Governance Studies (JIPAGS).

Kouzes, J. M., \& Posner, B. Z. (2004). Leadership The Challenge. Erlangga.

M. Munir Dan Wahyu Ilaihi, (2009). Manajemen Dakwah, Jakarta: Kencana.

Marginingsih,Ria.(2016). Kepemimpinan Karismatik Sebagai Employer Branding. Jurnal Bisnis Darmajaya.

Revly Sian Lizard, dkk. Efektivitas Program Pemberdayaan Masyarakat Miskin Di Kelurahan.

Paal Dua Kecamatan Paal Dua Kota Manado. Jurnal Ilmu Pemerintahan. Vol.2 No.2, 2017.

Saepudin, T. (2013). Pertumbuhan Modal Manusia Dan Pertumbuhan Ekonomi Antar Daerah Di Indonesia. Semnas Fekon: Optimisme Ekonomi Indonesia 2013, Antara Peluang dan Tantangan, 23.

Sjafri, Agus.(2014). Kemiskinan Dan Pemberdayaan Kelompok. Yogyakarta : Graha Ilmu.

Soerjono Soekanto.(2002) Sosiologi Suatu Pengantar. Jakarta: Raja Grafindo Persada.

Subejo Dan Supriyanto. (2004), Metodologi Pendekatan Pemberdayaan Masyarakat, Bahan Kuliah: Pemberdayaan Masyarakat Pedesaan, Universitas Gajah Mada Yogyakarta.

Suhardono, Edy. (1994). Teori Peran: Konsep, Derivasi Dan Implikasinya . Jakarta: Gramedia Pustaka Utama. 
Totok Mardikanto, Poerwoko Soebiato.

(2015). Pemberdayaan Masyarakat, Bandung:Alfabeta.

Wirawan. (2014). Kepemimpinan, Teori,Psikolog, Prilaku Organisasi, Aplikasi Dan Peneltian. Jakarta: Rajawali Pers.

Wirjana, B. R., \& Supardo, S. (2006). Kepemimpinan Dasar-Dasar Dan Pengembangannya. Yogyakarta:

Perpustakaan Nasional.

Totok Mardikanto, Poerwoko Soebiato. (2015). Pemberdayaan Masyarakat, Bandung:Alfabeta.

Kapita, F., Kaawoan, J. E., \& Lengkong, J. P. (2016). Peran Kepala Desa Dalam Pemberdayaan Masyarakat ( Suatu Studi Di Desa Wayafli Kecamatan Mabakabupaten Halmahera Timur). Jurnal Ilmu Pemerintahan, 14.

Negara, T. C. (2017). Peran Optimalisasi Pemberdayaan Nelayanterhadap Peningkatan Usaha (Studi Pada KUBKUB Nelayan Di Kabupaten Pati). Teknikom, 29. 